\title{
"The highest traditions of any service": The US Coast Guard's attempt to save the British Collier Wellington
}

\section{Robert M. Browning Jr.}

\begin{abstract}
Au cours de la Première Guerre mondiale, des navires de la Garde côtière américaine ont été déployés sous le commandement opérationnel des Forces navales des États-Unis vers les théâtres de guerre. L'un des exploits guerriers les plus célèbres de la Garde côtière a mis en jeu le garde-côte américain Seneca, une escorte de convoi pour les expéditions entre la Grande-Bretagne et Gibraltar. La présente note de recherche raconte la tentative vaillante mais tout de même ratée de l'équipage du Seneca de sauver le navire charbonnier britannique Wellington qui avait été abandonné par son propre équipage après avoir été torpillé.
\end{abstract}

Just after 1000 on Friday 13 September 1918, under partly cloudy skies and in a moderate sea, the US Coast Guard Cutter Seneca got underway from Milford Haven, Wales. She joined the twenty-one ship convoy OM 99 that formed in the roadstead with a destination of Gibraltar. This convoy would be Seneca's twentysixth trip and became one of the United States Coast Guard's most famous exploits during the First World War. ${ }^{1}$

The coast guard entered the war on 6 April 1917, the day that Congress declared war on Germany. Coast Guard Headquarters sent orders by telegraph to all its commands acknowledging the transfer of the service to the US Navy. During the war the coast guard performed many different duties in the European theatre. Six cutters steamed overseas, and operated out of Gibraltar, protecting convoys from this point to the United Kingdom and back. The coast guard's convoy work was its most valuable duty, but the massive nature of the conflict overshadowed these efforts. The cutters and crews performed with professionalism and without fanfare.

\footnotetext{
${ }^{1}$ The author would like to thank Dr. Christian Osterselthe for his assistance with the German navy documents. Seneca log, 13 September 1918, Bureau of Naval Personnel, Record Group (RG) 24, Ships Logs, Stations, and Miscellaneous Units, 1861-1947, National Archives and Records Administration (NARA), Washington DC.
}

The Northern Mariner/Le marin du nord, XXVII, No. 2 (Apr. 2017), 163-174. 


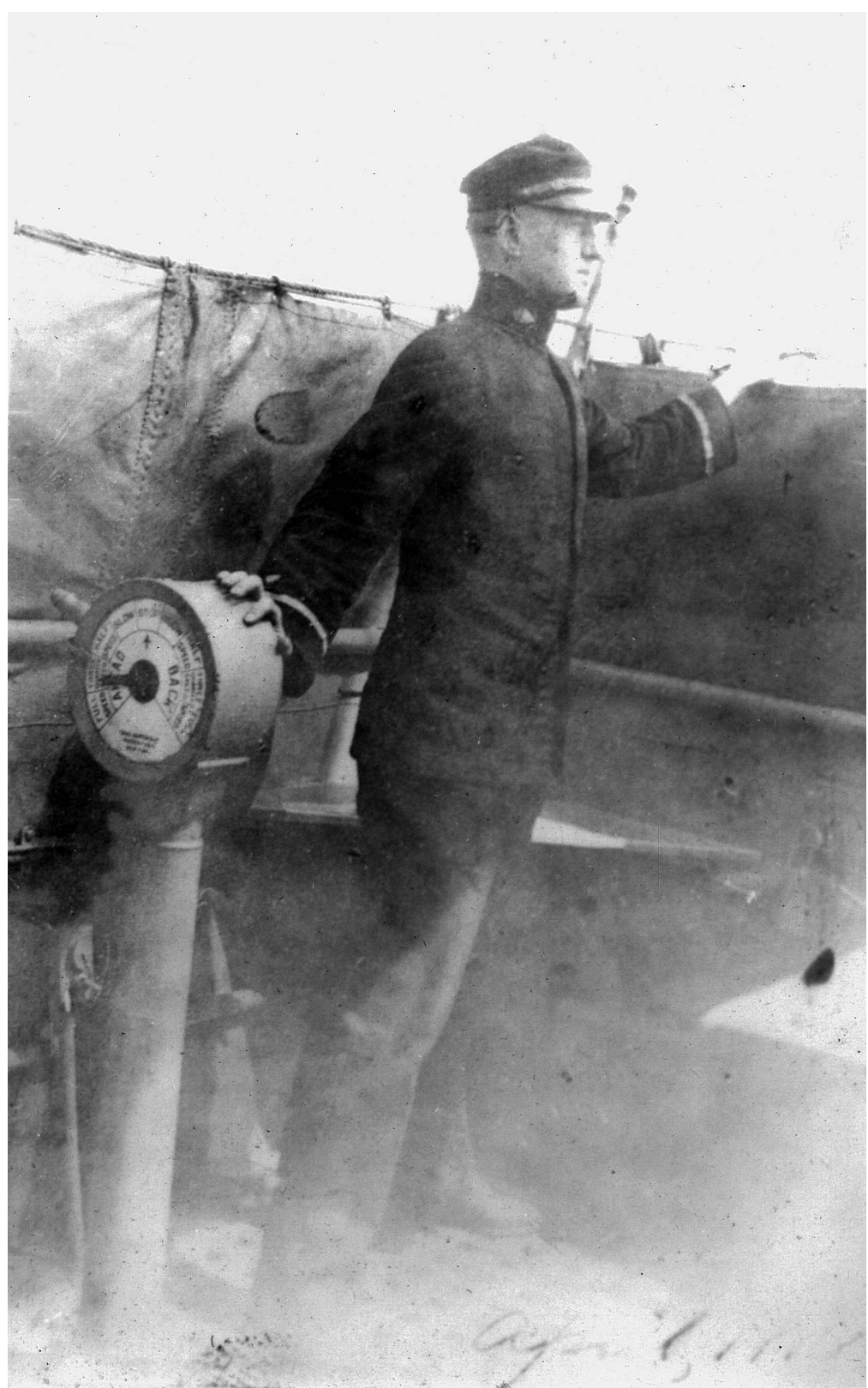

Third Lieutenant Fletcher Webster Brown poses on the bridge of a Coast Guard cutter 
The cutters were a welcome force due to the paucity of escort vessels. The 1,259-ton Seneca, built to destroy derelict hulks that floated along the east coast of the United States, was perfect for convoy work. Designed for long cruises, she had good sea keeping characteristics and a far-reaching cruising radius. In peace these qualities made her ideal for service in 1913 on the International Ice Patrol to track icebergs in the North Atlantic shipping lanes; in war she was perfectly fitted for convoy duty in Europe.

Convoys generally lasted seven to ten days depending on the speed of the slowest ship in the group and the route taken. The cutters maintained communications among the vessels, served to keep the enemy submarines at a distance, preserved the formations of the convoys, and facilitated communication with the British admiralty. The low speed and poor manoeuvring qualities of the merchant vessels made it difficult for them to keep their convoy stations and the dangers of collision were constant. This kept the crews alert especially in fog and foul weather. ${ }^{2}$

Convoy OM 99 had proceeded southward surrounded by ten British escorts and the Seneca. On Sunday night, 15 September 1918, about 300 miles southwest of their starting point, the British warships, having protected the convoy through the "danger zone," returned. This left the Seneca as the sole protection for the convoy until the group would later pick up new escorts out of Gibraltar to protect them in that danger zone. Convoy OM 99 initially proceeded at six knots in a formation columns. The columns of ships were to remain 600 yards apart and to keep 400 yards between the rows. Over the three days, seven ships either dropped out or detached to other ports, leaving the Seneca protecting fourteen ships. ${ }^{3}$

On 16 September, west of the Bay of Biscay, with the convoy proceeding in "poor formation," the commanding officer of the Seneca, Captain William J. Wheeler, a twenty-two-year veteran of the service, began trying to reorganize the group. Seneca, which had been zigzagging ahead of the convoy, slowed, intending to coral the stragglers, and to get the convoy into the prescribed formation. Minutes later, just before 1130, lookouts on the 5599-ton collier SS Wellington, the first ship in the fourth column, spotted a U-boat surface and quickly submerge again just aft of the starboard quarter. Carrying coal, with a destination of Naples, Italy, the Wellington had managed to steam a few hundred yards ahead of her station. In front of the convoy formation, she was a prominent target. A single torpedo fired at 550 yards from the $U-118$ (Kaptlt Herbert Stohwasser) nearly missed the ship, striking the collier's port side at the stem. The explosion ripped away a large section of the

\footnotetext{
${ }^{2}$ William J. Wheeler, "Reminiscences of World War Convoy Work," US Naval Institute Proceedings 55:5 (May 1929), 385-86; Seneca File, USCG Historian's Office, Washington, DC.

${ }^{3}$ There are great discrepancies of the times within the documents. Weather delayed the convoy and it arrived 2100 on 20 September at Gibraltar, fifteen hours late. Secret List of ships in OM 99 Convoy, Telegram 15 September 1918, Convoys OM 98 - OM 113, Convoy Records, ADM137/2627, The National Archives (TNA), Kew, England; Secret List of Ships in OM.99 Convoy, and Schematic of Vessels in OM.99, ibid; William J. Wheeler, "Reminiscences of World War Convoy Work," 385; Seneca log, 13 September 1918; Seneca War Diary, 16 September 1918, General Correspondence, 1910-1941, Scope of Operations, Box 1186, Entry 283A, RG 26, NARA.
} 
forefoot and damaged the collision bulkhead, allowing water to flood the number one hold. ${ }^{4}$

The blast brought Captain Wheeler hurriedly to the Seneca's bridge. He ordered the general alarm sounded and rang for all speed. The Wellington lay off the port quarter and the cutter steamed quickly in her direction, standing through the oncoming convoy formation. A minute after the explosion, the $U-118$ surfaced close to the Wellington's bow. Seneca's 4-inch gun fired three rounds at the conning tower. Nearby merchant ships fired another three shots as the $U-118$ disappeared under the water. At 1132, Wheeler ordered the first depth charge dropped and the gun crews began systematically firing to keep the submarine submerged. She dropped an additional seven depth charges and the crew fired thirty-five shots as she steamed in circles around the Wellington, before ending the attack. The depth charge explosions damaged the $U-118$, and she limped away unable to follow the convoy. Seneca then positioned herself aft of the Wellington. ${ }^{5}$

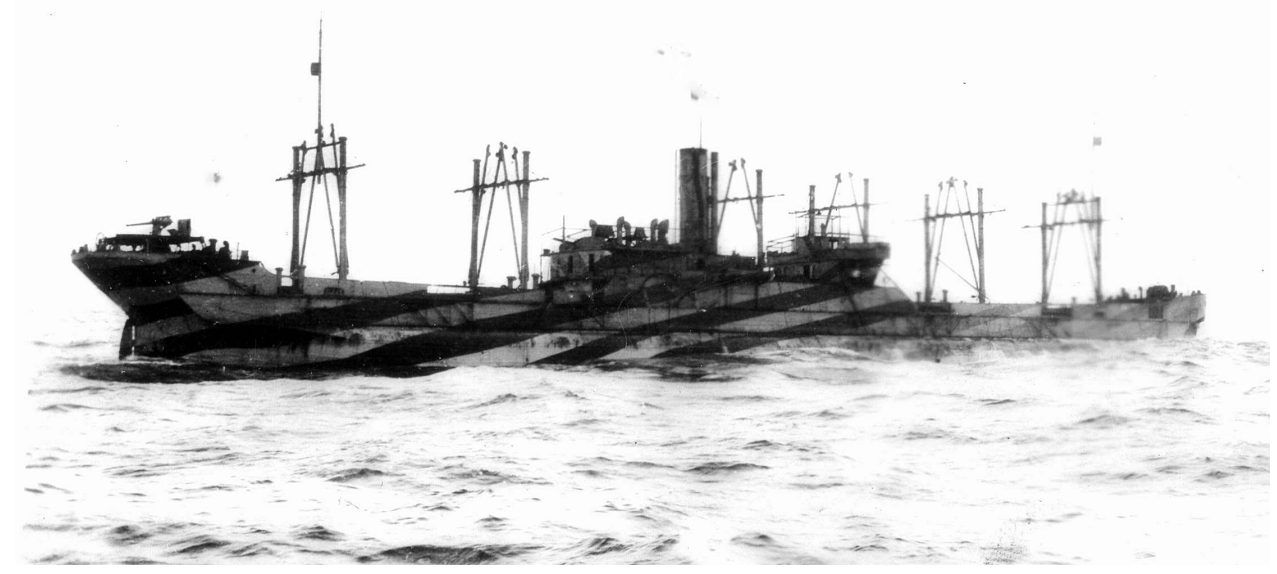

A shot of the Wellington taken from the deck of the Seneca. Note the damage at the forefoot.

\footnotetext{
${ }^{4}$ The entire article uses the unpublished manuscript entitled "Browns Story," Fletcher Brown Collection, USCG Historian's Office, Washington DC; Secret List of ships in OM 99 Convoy, Telegram 15 September 1918; Cablegram 19 September 1918, Ibid. Records of Convoy OM 99, Convoy Records; ADM137/2627, TNA; William Wheeler to Commander, US Patrol Squadrons Based at Gibraltar, 18 September, Seneca Vessel File, Subject File 1911-1927, Box 1333, Entry 520, Naval Records Collection of the Office of Naval Records and Library, RG 45, NARA; Seneca War Diary, entry for 16 September 1918, Box 1186, Entry 285A, RG 26, NARA.

${ }^{5}$ Brown to Wheeler, 5 November 1918, Wellington Vessel File, Subject File, 1911-1927, Box 1587, Entry 520, RG 45, NARA; Two of the depth charges failed to explode. Form for Reporting Attacks on Convoys, Ibid; William Wheeler to Commander, US Patrol Squadrons Based at Gibraltar, 18 September 1918, Seneca Vessel File, Box 1333, Entry 520, RG 45, NARA. Recommendations for Improvement in Convoy System, 20 September 1918, William Wheeler,
} 
This was Wellington's second encounter with a U-boat's torpedo. On 19 October 1917, while steaming off Portland Bill in the English Channel, the UB 40 attacked and severely damaged her. An armed drifter towed her to safety and, after repairs, she went back in service. This was her first trip after these repairs. ${ }^{6}$ Wellington's crew were new to the vessel and would not wait for assistance. They abandoned the ship even though she was not in immediate danger of sinking. Three boats carrying all hands approached the Seneca. The master, William C. Donovan, began signaling to the Seneca as he and the crew approached, relating the damage, and that his men refused to remain on the vessel. He also made clear that he wanted assistance to save his ship.?

First Lieutenant Fletcher Webster Brown, Seneca's navigating officer, was on the bridge at the time of the attack. Brown, a native of Brockton, Massachusetts, took his oath as a cadet on 8 May 1908. After graduating from the Revenue Cutter Service School of Instruction, he served in the cutters Woodbury, Pamlico and Ossippee until attached to the Seneca. In his short career, he already had over six years of sea duty. ${ }^{8}$

Brown immediately asked for permission to try to save the Wellington. Wheeler, approved, but told him he would order no one on "such a desperate enterprise." Brown asked for volunteers and nearly the entire crew stepped forward to help get the merchant vessel to port. Brown picked one acting warrant and seventeen enlisted men, including USN Gunner's Mate, $2^{\text {nd }}$ Class Paul Marvelle who was temporarily attached to the Seneca, to follow him. Seventeen-year-old Boy First Class James "Smiling Jimmy" Nevins, who stood only five feet, four inches tall, however, cried when Brown refused to allow him a seat in the boat. He pleaded with Brown continuously to take him and Brown finally assented. At about 1230 they clambered over the side into a boat. Captain Donovan of the Wellington, his first and second officers, and the assistant engineer, persuaded eight of their crew to join the coast guard attempt to save the Wellington. ${ }^{9}$

At 1235 the Seneca steamed away to rejoin the convoy, leaving the wounded vessel behind. Wheeler had his radio operator send a message for assistance. The USS Warrington (DD-30) was escorting another convoy about eighty miles north

\footnotetext{
Box1185, Entry 283A, RG 26, NARA; Collection of Foreign Records Seized, Records of the German Navy, 1850-1945, U-118 War Journal, 16 September 1918, Roll 30 Item 61699, RG 242, Microfilm Publication T1022, U-boat and T-Boat War Journals, NARA.

${ }^{6}$ www.uboat.net

${ }^{7}$ William Wheeler to Commander, US Patrol Squadrons Based at Gibraltar, 18 September 1918, Seneca Vessel File, Box 1333, Entry 520, RG 45, NARA.

${ }^{8}$ Records of Officer Personnel, 1797-1913, Entry 265, RG 26, NARA, entry for Fletcher W. Brown; Register of the Officers and Vessels of the Revenue-Cutter Service of the United States, Washington, GPO, 1914, 1915,1916, 1917

9 Ibid; Wheeler, "Reminiscences of World War Convoy Work," 390-391; New York Times "10 Americans Perish Trying to Save Ship," 22 September 1918; James Nevins, Service Record, National Personnel Records Center, St. Louis.
} 
of the reported position. At 1300 she was ordered to leave her westbound convoy and proceed to the Wellington's assistance. ${ }^{10}$

As Brown's party pulled towards the merchant ship, Brown assigned duties to the men. He detailed who would stand as lookouts, those who would get the engines restarted and the men who would serve the single 4-inch gun. On board, the men went to their posts and they broke out ammunition in case the submarine returned. Marvelle took charge aft and gave instructions to the merchant crew. ${ }^{11}$

Acting Warrant Machinist William L. Boyce with Wellington's assistant engineer went below to check the engines. However the merchant officer was so new to the vessel he did not have the experience needed; thus the "work was done largely under the able supervision of Machinist Boyce." Boyce returned with the news that the boiler still had 120 pounds of steam and that with a few adjustments to the air pump they could get underway in thirty minutes. Meanwhile Wellington's first officer had gone below to take soundings. He returned with the news that the number two tank was dry. By 1250, the Wellington was under way again. ${ }^{12}$

Brown hoped to get the ship to Brest, France some 300 miles distant. At first speed was slow due to the damage at the stem and the lack of steam in the boilers. Brown stopped the ship for a while to allow steam pressure to build in the boilers and by 1410 had her again underway. At seven and a half knots they steered towards Brest.

Once underway, Brown ordered the men to construct life rafts. One was fashioned large enough for the entire crew. Using heavy joists from the main hatch, they laid it on the number three hatch and cleared all the guys and tackle nearby so that it would float off the vessel unencumbered should she sink. Three others were constructed and placed on the port side. Meanwhile, others in the rescue party continually took soundings in the \#2 hold. Reports returned that water was rising in this compartment, but with pumps, they could hold the level at three and a half feet. Periodically Brown had the ship hove to, to allow the pumps to work under full steam to keep ahead of the water. ${ }^{13}$

There were only six men from the engine room force on board. To keep the engines running effectively, Brown sent down other men to oil the machinery and to pass coal. The men took turns below and were in turn relieved to take stations as lookouts and on the guns. Despite the hard work, the spirit of the men remained

\footnotetext{
${ }^{10}$ Extract from Letter of Lieut. Commander Van der Veer to Robert H. Dunn, 1 October 1918, James Nevins, Service Record, National Personnel Records Center, St. Louis; Wheeler to Captain Commandant, 9 November 1918, Seneca Vessel File, Box 1333, Entry 520, RG 45, NARA; Warrington Log, 16 September 1918, RG 24, NARA.

${ }^{11}$ Convoy records incorrectly indicate that fifteen officers and men of Wellington's crew reboarded her. Records of Convoy OM 99, Convoy Records; ADM137/2627, TNA; Van der Veer to Commander, US Naval Forces in France, 18 September 1918, Warrington Vessel File, Box 1410, Entry 520, RG 45, NARA.

${ }^{12}$ Wheeler to Captain Commandant, 9 November 1918, Seneca Vessel File, Box 1333, Entry 520 , RG 45, NA

${ }^{13}$ Brown to Wheeler, 5 November 1918, Wellington Vessel File, Box 1587, Entry 520, RG 45, NARA. "Browns Story" mentions only the large raft.
} 
excellent, aided by Cook Russell Elam who prepared meals for the men and had everyone on board fed by $1430 .{ }^{14}$

The collier's progress towards her destination went well all afternoon. By sunset however, the wind and the sea began to pick up, and gradually it became impossible to keep the ship on course. At 1845, Brown stopped the ship because, with her bow down, she had gradually worked her head to sea. At 1915 with more steam pressure, she was back on course. The weather continued to worsen and with the wind increasing to near gale force, the crew could not hold the Wellington on course. Unable to construct a sea anchor, Brown tried unsuccessfully to steam her stern first to keep her headed in the proper direction. Then seas began to crash over the bow and through the \#1 hatch.

The Wellington was a uniquely-designed "Turret Deck" ship. Her rounded hull curved inward above the load line, creating a horizontal area, fore and aft termed the "harbour deck." With the ship down by the head, this deck acted as a diving rudder, driving the ship's bow farther in the water. A plate on the harbour deck had worked loose, allowing more water to seep into the ship. The waist of the ship was now unsafe and the forecastle was unreachable. Brown found it necessary to stop the ship more frequently to allow the pumps to clear the water from the ship. ${ }^{15}$

Radio communication with the Warrington kept her commanding officer apprised of the Wellington's situation. The early reports made by Electrician Second Class Morrill C. Mason relayed that they thought they could keep the collier afloat. Within minutes of one of the updates later that evening, the bulkhead separating the number one and two holds collapsed, (a result of improper repairs made to the ship after the torpedo attack eleven months earlier), letting water pour into the ship. Brown now had no choice but to abandon ship. ${ }^{16}$

Brown had ordered that one of the collier's boats be trailed astern with a long painter, but the rough seas parted the line. This left only a small jolly boat, later damaged beyond use, and a large lifeboat. Wellington's large double- ended lifeboat, outfitted with air tanks, could carry forty-one persons. This boat hung on the port side. With a port list, Brown believed he had to launch the boat immediately, or risk losing it altogether, as the worsening weather threatened to take the boat under at each roll. ${ }^{17}$

Just after 0200 on 17 September, Brown mustered all hands at the remaining lifeboat except for Boyce and two others who worked the pumps and the radio operator who kept in touch with the Warrington. He thought that this small group might keep the ship afloat while the others left. The merchant crew began climbing into the boat, while the Seneca's men remained on deck to clear the boat from the

\footnotetext{
${ }^{14}$ Ibid.

${ }^{15}$ Brown relates that the damage to the plate occurred when the $U B 40$ torpedoed her a few months before.

${ }^{16}$ Brown to Wheeler, 4 November 1918, Fletcher Brown Collection, USCG Historian's Office; Robert H. Dunn, "Here is the Wellington Story," 1 October 1918, Box 1185, Entry 283 A, RG 26, NARA.

17 “Brown's Story,” USCG Historian's Office.
} 
side. Brown, overseeing this operation, had to leave to receive a message from the Warrington. Seven of the merchant crew, including Warrington's first and second officer, and one of Seneca's men were in the boat and the rest planned to enter it by climbing down the falls. At 0230, with Brown still away, one of the merchant crew cast off the bow painter. The current quickly swung the boat around and one of the merchant crew cast off the stern painter fearing the boat would smash against the ship's side. The current swept the boat quickly away before any of the other coast guardsmen could slide down the falls into the boat. This left a couple of men clinging to the davits and two on the falls. As the boat drifted to leeward, the first officer in the boat tried to work his way back alongside the collier, but the current was more than the inexperienced oarsmen in the boat could stem. The boat gradually drifted away. ${ }^{18}$

The Wellington's master and four of his crew and Brown and eighteen of the Seneca's volunteers were left on board. Warrant Machinist Boyce and Oiler Second Class George Christy hurried below to "bleed the boilers," shut off the fans, and open the fire doors to prevent a boiler explosion. Boyce remained in the fire room until there was no chance that the boilers would explode when the ship submerged. As the forecastle gradually settled, Brown and the others now had little time. Brown ordered rockets sent up to signal the Warrington their whereabouts. Warrington spotted these rockets and answered. ${ }^{19}$

When the Warrington had detached from her convoy, she had hoped to join the Wellington within four hours, about at 1700 . Unfortunately Wellington's position had been incorrectly reported, and she was forty miles farther away. The deteriorating weather had further delayed the destroyer's arrival. As she neared the sinking collier, the three-quarter moon had just set and darkness made the rescue operations that much more difficult. Lookouts on the Warrington spotted the lifeboat with the eight survivors including Assistant Master at Arms Daniel E. Grimshaw from the Seneca. Warrington's commanding officer, Lieutenant Commander Norman R. Van der Veer rescued those in the boat first. He planned to have this craft return and pick up the remaining men, but the heavy seas swamped the boat while it lay alongside the destroyer. ${ }^{20}$

\footnotetext{
${ }^{18}$ Wheeler to Captain Commandant, 9 November 1918, Seneca Vessel File, Box, Box 1333, Entry 520, RG 45, NARA; Van der Veer to Commander, US Naval Forces in France, 18 September 1918, Warrington Vessel File, Box 1410, Entry 520, RG 45, NARA; Wheeler, "Reminiscences of World War Convoy Work," 391.

${ }^{19}$ Brown to Reynolds 23 December, Fletcher Brown Collection, USCG Historian's Office; Wheeler, "Reminiscences of World War Convoy Work," 391; Warrington Log, 16 September 1918, RG 24, NARA; New York Times "10 Americans Perish Trying to Save Ship," 22 September 1918.

${ }^{20}$ Wheeler to Commander, US Patrol Squadrons Based at Gibraltar, 18 September 1918, Seneca Vessel File, Box 1333, Entry 520, RG 45, NARA; Van der Veer to Robert H. Dunn, 1 October 1918, Fletcher Brown Service Record, National Personnel Records Center, St. Louis MO; Brown to Reynolds 23 December, Fletcher Brown Collection, USCG Historian's Office; Van der Veer to Commander, US Naval Forces in France, 18 September 1918, Warrington Vessel File, Box 1410, Entry 520, RG 45, NARA; Wheeler to Bertholf, 9 November 1918 Seneca Vessel File, Box, Box 1333, Entry 520, RG 45, NARA.
} 
Van der Veer began his search for other boats, but in the darkness and rough seas nearly killed two men in the water. He realized he had to make an approach from the leeward side of the Wellington and float down towards the survivors. He ordered the deployment of three life rafts, Franklin Lifebuoys and several circular buoys, all with lights. He carefully manoeuvred his ship through the wreckage, the life rafts, and the buoys to pick up the survivors. Just after 0500, Van der Veer tried to deploy one of his boats, but the heavy seas damaged it. Instead, three rescue swimmers jumped into the water with lines secured about their waists to rescue Water Tender William Best, who unfortunately did not survive. These three sailors were awarded the Silver Lifesaving Medal for their efforts. ${ }^{21}$

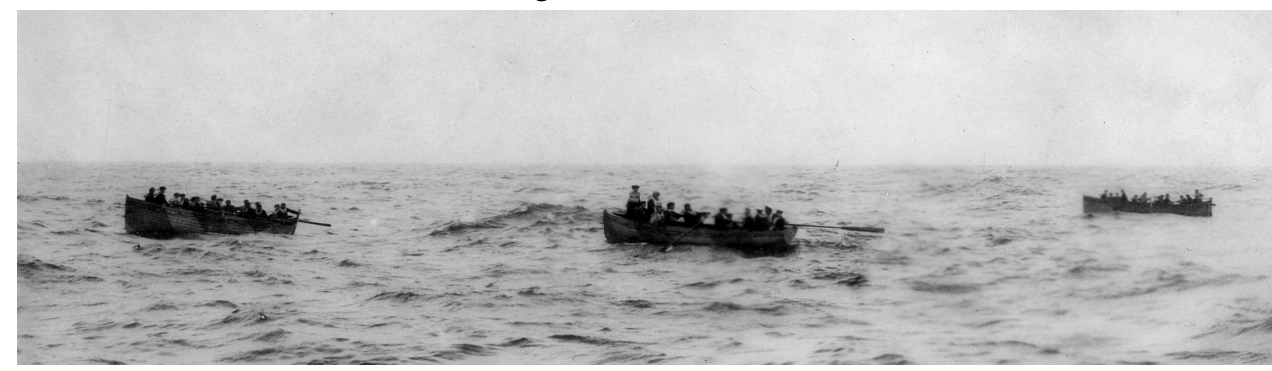

A close up of the boats of Wellington approaching the Seneca

The remaining men on the Wellington now gathered at the stern. They had no boats, and the large raft they constructed did not float free and would go down with the collier. The men had to go into the water with only their life vests and the few smaller rafts. Before they abandoned ship, Jimmy Nevins noted that Brown still had his rubber boots on and leaned over to cut the rawhide lacings of the boots and then pulled them from his feet. The last men left were Brown, Boyce, Mason and two in the fire room. Brown ordered the last men into the water, and with a flashlight, he made one last signal to the Warrington, "My men are in the water." At about 0400, the Wellington listed heavily and in the "inky darkness" disappeared beneath the water. As Wellington took her final plunge, Brown leaped clear and escaped the vortex of the sinking ship. ${ }^{22}$

When Brown went into the sea the Warrington was about 1200 yards away, close enough for him to see men lining the rail. He swam in the direction of the destroyer, looking for something that would keep him afloat. He spotted two calcium lights to his left and swam in that direction thinking they marked a life raft. $\mathrm{He}$ found that they were only the lights themselves and extinguished them so no others would make the same mistake. Brown spent three and a half hours in the

\footnotetext{
${ }^{21}$ Extract from letter of Lieut. Commander Van der Veer to Robert H. Dunn, 1 October 1918, Seneca Vessel File, Box 1333, Entry 520, RG 45, NARA; Herzinger Statement 26 September 1918, Warrington Vessel File, Box 1410, Entry 520, RG 45, NA; Warrington Log, 16 September 1918, RG 24, NARA.

${ }^{22}$ Wheeler to Captain Commandant, 9 November 1918, Seneca Vessel File, Box 1333, Entry 520 , RG 45, NARA; Van der Veer to Commander, US Naval Forces in France, 18 September 1918, Warrington Vessel File, Box 1410, Entry 520, RG 45, NARA.
} 
water, sustaining himself while clinging to a plank. He never remembered how he made the last 100 yards and ended in the hospital with double pneumonia.

During the night, all the men encouraged their shipmates and attempted to keep each other alive. Master Donovan, who could not swim, was one of the men they tried to assist. Left clinging to wreckage, however, most of them gradually lost their battle to survive due to hypothermia. During the night, Coxswain James C. Osborn found one of the smaller life rafts constructed on the Wellington and dragged Coxswain Jorge A. Pederson on it. He performed lifesaving treatments to get the water from his lungs and "slapped him into consciousness." The heavy seas continually washed Pederson off the raft and when this occurred, Osborn retrieved him. For thirty minutes, he kept Pederson on the raft, holding him with his feet to keep him from slipping off. After lookouts on the Warrington spotted the two, Osborn signalled by semaphore "I' $m$ all right; but he's gone unless you come right away.",23

The Warrington remained in the area until 1030 the following morning looking for survivors. There were nine survivors from the Seneca and eleven dead. Only seven survivors of the Wellington's crew were rescued; Donovan was among the dead. $^{24}$

For their deeds, all but one of the coast guard boarding party, both living and deceased received the Navy Cross. The Treasury Department also awarded Osborn the Gold Lifesaving Medal for his effort to keep Pederson alive. Warrant Officer William Boyce received the Distinguished Service Medal for his efforts below deck. Brown, however, felt that all should have received the Distinguished Service Medal which was then higher in precedence than the Navy Cross. On 4 February 1919, Congress had created both the Navy Cross and the Distinguished Service Medal for the navy with the award retroactive to 6 April 1917. Feeling slighted, Brown refused to accept his Navy Cross. Brown wrote the commandant, William E. Reynolds, that his men went to the Wellington "took command of her, went into her bowels and raised steam, snatching her from the very maw of the Hun, only to be beaten by God Almighty, [and] have been awarded THE NAVY CROSS, the third and lowest decoration." 25

Brown continued for some time lobbying the navy to secure a higher award. $\mathrm{He}$ corresponded with Rear Admiral William Sims, who was sympathetic to Brown. The admiral wrote that he believed that Brown would eventually receive the greater

\footnotetext{
${ }^{23}$ Van der Veer to Secretary of the Navy, 26 September 1918, Warrington Vessel File, Box 1410, Entry 520, RG 45, NARA; Wheeler to Bertholf, 9 November 1918, Seneca Vessel File, Box 1333, Entry 520, RG 45, NARA; Dunn, "Here is the Wellington Story," 1 October 1918, Box 1185, Entry 283 A, RG 26, NARA.

${ }^{24}$ Van der Veer to Commander, US Naval Forces in France, 18 September 1918, Warrington Vessel File, Box 1410, Entry 520, RG 45, NARA.

${ }^{25}$ Brown related that Admiral William Sims recommended him for the Distinguished Service Medal and there is evidence that the navy considered all the men. Brown to Reynolds 23 December, Fletcher Brown Collection, USCG Historian's Office; Roosevelt to J. L. Adams, 17 May 1919, William H. Prime Service Record, National Personnel Records Center, St. Louis.
} 


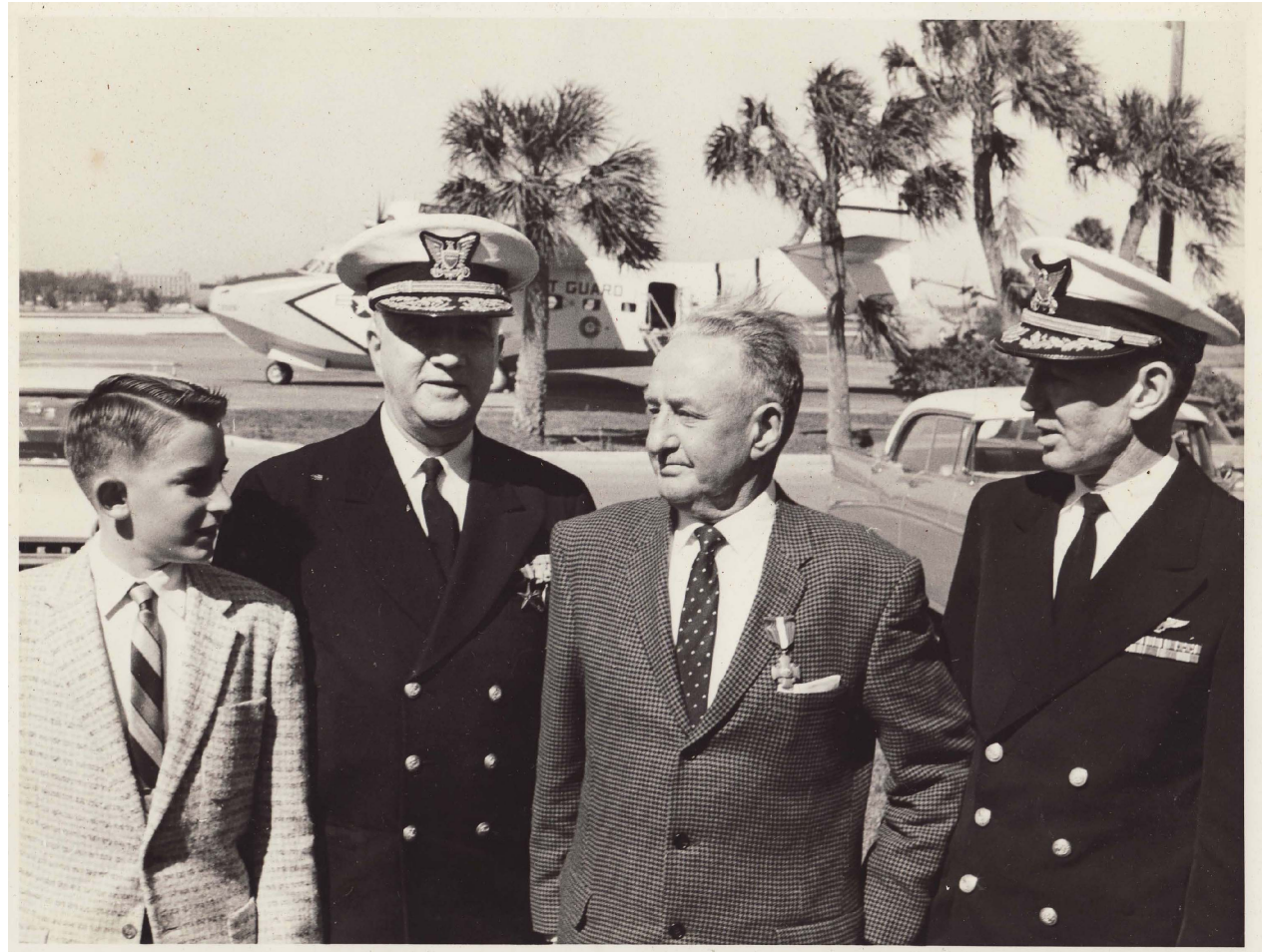

Fletcher Brown poses with his Navy Cross shortly after receiving the award from Commandant Alfred C. Richmond. From left to right-Fletcher Brown III, Admiral Alfred C. Richmond, Fletcher Brown and Commander Fletcher Brown Jr.

honour. Senators Henry Cabot Lodge and Joseph Sherman Frelinghuysen also backed Brown in his quest. ${ }^{26}$

The recognition, however, was never changed and Brown refused to accept his medal for nearly forty years. In 1959, several years after he had retired, he wrote Coast Guard Headquarters to inquire about advancement in rank he was entitled to, based on his Navy Cross award some forty years earlier. During the interlude since the First World War, the stature of the Navy Cross had changed. In 1942, Congress revised the law making it second only to the Medal of Honor in importance. The answer returned to Brown was that he was not eligible for the advancement because he had not accepted the medal and thus, was not a recipient. Brown wrote back that the Service awarded the medal to him, but he declined to accept it. The matter eventually received Commandant Alfred C. Richmond's attention and in 1960, he personally presented the award at the St. Petersburg Air Station in the presence of

\footnotetext{
${ }^{26}$ Sims to Brown, 6 January 1920, Fletcher Brown Service Record, National Personnel Records Center, St. Louis MO, Lodge to Frelinghuysen, 25 September 1920, Ibid; Wheeler to Reynolds 12 December 1920, Ibid.
} 
his son, coast guard Commander Fletcher Brown Jr., and his grandson Fletcher Brown III who would also join the US Coast Guard. ${ }^{27}$

Brown's acceptance ended one of the most heroic episodes in the history of the US Coast Guard. Contemporary writers had immediately recognized the valour of this event and related the story in newspapers, books, and articles. War correspondent Frazier Hunt, of the Chicago Daily Tribune, said about this event: "in all the long lists of brave things done in this war none has been finer." Captain Wheeler though probably paid the highest compliment by writing the coast guard commandant that "Lieutenant Brown and the gallant volunteers set an example worthy of the highest traditions of any Service or any Nation."28

\footnotetext{
${ }^{27}$ The act of Congress of 4 March 1925, allowed officers in the navy, marine corps, and coast guard promotions of one grade upon retirement if they received special commendations for performance of duty in actual combat. Colloquially known as "tombstone promotions," they conferred the prestige of the higher rank but not the additional retirement pay. The only benefit was to allow the recipients to utilize their higher ranks on their business cards and tombstones. Brown to A.C. Richmond, 23 January 1959, Richmond to Brown 21 October 1959, Brown to Richmond 4 November 1959, Fletcher Brown Collection, USCG Historian's Office.

${ }^{28}$ Chicago Daily Tribune, 22 September 1918; Wheeler to Bertholf, 9 November 1918, Entry 520, RG 45, NARA.
} 